\title{
Hak Aksesbilitas Dalam UU No. 8 Tahun 2016 Bagi Penyandang Disabilitas Netra Di Kota Serang
}

\author{
Harum Mukrimah \\ Ilmu Pemerintahan, Fakultas Ilmu Sosial dan Ilmu Politik, Universitas Sultan Ageng Tirtayasa, Serang. \\ mukrimahharum@gmail.
}

\section{Yeni Widiastuti}

Ilmu Pemerintahan, Fakultas Ilmu Sosial dan Ilmu Politik, Universitas Sultan Ageng Tirtayasa, Serang. Yeni_arh@yahoo.co.id

\begin{abstract}
Abstrak
Sebagai penyelenggara pemenuhan fasilitas publik pada warga negara, pemerintah memiliki peran menjadi pelindung atas terpenuhinya kemudahan aksesbilitas warga negara, salah satunya penyandang disabilitas. Sudah adanya UU No. 8 Tahun 2016 Tentang penyandang Disabilitas yang menjamin posisi mereka sebagai warga negara karena penyandang disabilitas memiliki kedudukan, hak, dan kewajiban yang sama tanpa membeda - bedakan. Penelitian ini menggunakan teori Implementasi Kebijakan dari Thomas B. Smith dalam Akib (2010). Metode yang digunakan ialah kualitatif deskripstif. Teknik pengumpulan data yang digunakan ialah wawancara, observasi, dan studi dokumentasi. Hasil dari penelitian menunjukan bahwa Kota Serang belum optimal dalam memenuhi hak aksesbilitas bagi disabilitas netra. Rekomendasi dari penelitian ini adalah Pemerintah Kota Serang harus mendorong Perda Kota Serang untuk segera terbit karena dengan adanya Perda dapat memperkuat hak- hak penyandang disabilitas yang ada si Kota Serang.
\end{abstract}

Kata Kunci : hak aksesbilitas, implementasi kebijakan, penyandang disabilitas netra

\section{Abstract}

As an organizer of fulfilling public facilities for citizens, the government has a role to be a protector of the fulfillment of the accessibility of citizens, one of them with a disability. Law No. 8 of 2016 concerning persons with disabilities that guarantees their position as citizens because persons with disabilities have the same position, rights and obligations without distinction. This study uses the theory of Policy Implementation from Thomas B. Smith in Akib (2010). The method used is descriptive qualitative. Data collection techniques used are interviews, observation, and documentation studies. The results of the study show that Serang City has not 
been optimal in fulfilling the right of accessibility for person with disability. The recommendation of this study is that the Serang City Government must encourage the Serang City Regional Regulation to be published soon because with the Regional Regulation can strengthen the rights of persons with disabilities in the Serang City.

Keywords: accessibility rights, policy implementation, Disability netra community.

\section{Pendahuluan}

Negara menjadi pelindung bagi setiap warganya karena negara wajib untuk menyelenggarakan aksesbilitas publik yang dengan mudah dapat dijangkau oleh setiap warganya. Tanpa membeda - bedakan posisi mereka sebagai warga negara karena penyandang disabilitas memiliki kedudukan, hak, dan kewajiban yang sama dalam pasal 27 UUD 1945 dinyatakan bahwa : "Setiap warga negara berhak memperoleh pekerjaan dan penghidupan yang layak bagi kemanusian".

Konvensi Hak Penyandang Disabilitas (KHPD) adalah salah satu instrumen internasional HAM yang memuat aturan penghormatan, pemajuan, pemenuhan, dan perlindungan hak penyandang disabilitas secara komprehensif dan integratif. Bahkan konvensi tersebut telah diadopsi oleh Majelis Umum PBB pada tanggal 13 Desember 2006 di New York. Terdapat 50 pasal dan memuat hak-hak sosial, ekonomi, budaya, politik dan sipil secara komprehensif. Konvensi ini menandai adanya perubahan besar dalam melihat permasalahan kelompok masyarakat yang mengalami kerusakan atau gangguan fungsional dari fisik, mental, atau intelektual.

Dalam kovensi PBB di tahun 2006, para penyandang disabilitas dapat ikut serta dalam pembangunan. Dan juga UU yang baru cakupannya lebih luas dibanding sebelumnya, yaitu jika dalam UU No. 4 Tahun 1997 Tentang Penyandang Cacat yang masih menempatkan penyandang disabilitas sebagai objek dan bersifat belas kasihan. Lain halnya dengan UU No. 8 Tahun 2016 dimana penyandang disabilitas kedudukannya sebagai subjek (diakui keberadaannya) yaitu sebagai manusia yang bermatabat yang memiliki hak yang sama dengan warganya (Ratnaningsih, 2016).

Namun kenyataannya, sering kali tidak sepenuhnya aksesbilitas pada fasilitasfasilitas umum yang diterima oleh penyandang disabilitas dapat terpenuhi. Maka dari itu aksesbilitas dalam fasilitas publik untuk penyandang disabilitas menjadi penunjang utama bagi mereka untuk melakukan mobilisasi karena sejatinya, negara memberikan legitimasi bagi penyandang disabilitas dengan memberikan perlindungan hukum berupa hak aksesbilitas dipasal 18 bagi penyandang disabilitas yang telah diatur dalam UU No. 8 Tahun 2016 Tentang Penyandang Disabilitas.

Studi yang akan dilakukan oleh peneliti berkaitan dengan implementasi UU. No. 8 Tahun 2016 Tentang Penyandang Disabilitas dan aksesbilitas yang di dapat oleh penyandang disabilitas khusus netra yaitu trotoar khusus atau guiding block bagi penyandang disabilitas di Kota Serang dan fasilitas yang disediakan pada gedunggedung pemerintahan Kota Serang. Penelitian ini juga bertujuan untuk melihat sejauh mana kesiapan Kota Serang dalam memenuhi kebutuhan hak aksesbilitas dan hak fasilitas publik bagi penyandang disabilitas netra. 


\section{Kerangka Teori}

\section{Idealisasi Kebijakan}

Sudah terhitung dua tahun sejak diberlakukannya Undang- undang tentang penyandang disabilitas, yaitu UU Nomor 8 Tahun 2016 Tentang Penyandang Disabilitas. Namun sampai tahun 2018 hanya terdapat delapan Provinsi yang telah mengadopsi undang- undang tersebut menjadi Perda diantaranya; DI Yogyakarta, Jawa Timur, Jawa Barat, Jawa Tengah, DKI Jakarta, Bangka Belitung, Kepulauan Riau, dan Bali (Perwitasari, metrotv.news: 2017).

Hal ini juga yang menjadi salah satu permasalahan yang ada di Kota Serang. Pemerintah Kota Serang belum memiliki fisik Peraturan Daerah Kota Serang ataupun Peraturan Walikota Serang yang dapat mengakomodir semua hak- hak dan juga kebutuhan penyandang disabilitas begitu juga dengan pemenuhan hak penyandang disabilitas netra. Misalkan apa yang yang dilakukan dalam riset (Arinia, Hikmawan, \& Ma'asan Mayrudin, 2019) bercerita mengenai bagaimana kaum disabilitas mengorganisir melaui kebijakan. Dalam melakukan perumusan dan perencaan untuk membuat kebijakan yang ideal, dalam hal ini ialah hak aksesbilitas yang dilaksanakan oleh implementor seharusnya melibatkan beberapa stakeholder- stakeholder yang merasakan langsung apa yang menjadi kebutuhan penyandang disabilitas netra.

Berdasarkan hasil wawancara peneliti dengan Ketua PERTUNI (Persatuan Tuna Netra Indonesia) Cabang Kota Serang, dalam pembuatan dan perencanaan perda tentang disabilitas tidak mengikut sertakan PERTUNI sebagai lembaga yang mewadahi disabilitas netra dan sebagai invidu langsung yang merasakan apa yang menjadi kebutuhan penyandang disabilitas netra. Padahal dengan dilibatkannya penyandang disabilitas netra langsung, maka memudahkan implementor dalam membuat dan merumuskan kebijakan daerah tersebut karena secara langsung dapat mengetahui permasalahan- permasalahan yang dirasakan oleh penyandang disabilitas netra di Kota Serang.

\section{Metode Penelitian}

Jenis penelitian yang dianggap tepat untuk digunakan dalam tulisan ini ialah metode penelitian kualitatif. Menurut Creswell (2014:95) penelitian kualitatif dimulai dengan asumsi dan penggunaan kerangka penafsiran/teori yang membentuk atau memepengaruhi studi tentang permasalahan riset yang terkait dengan makna yang dikenakan oleh individu atau kelompok pada suatu permasalahan sosial atau manusia. Metode ini digunakan peneliti dalam mendeskripsikan tujuan dari penelitian yaitu mengenai implementasi hak aksesbilitas dalam UU No. 8 tahun 2016 bagi penyandang disabilitas di Kota Serang.

Dalam penelitian ini, peneliti menggunakan metode penelitian dengan pendekatan studi kasus. Menurut Yin dalam Creswell (2014:135) pendekatan studi kasus dalam kehidupan nyata, dalam konteks atau setting kontemporer. Dalam penelitian ini kasus yag dipilih dalam implementasi hak aksesbilitas dalam UU No. 8 tahun 2016 bagi penyandang disabilitas di Kota Serang, yaitu bagaimana kesiapan Pemerintah Kota Serang dalam melaksanakan UU No. 8 Tahun 2016 Tentang Penyandang Disabilitas. 


\section{Hasil dan Diskusi}

Koordinasi antara pihak pemerintah dengan penyandang disabilitas netra langsung juga perlu, hal ini bertujuan agar dalam setiap pembuatan perencanaan terkait pembangunan fasilitas umum yang mudah diakses oleh penyandang disabilitas khususnya diabilitas netra. Fasilitas umum yang dibangun berupa interior dalam dan luar pada bangunan gedung pemerintahan dan kebutuhan- kebutuhan lainnya bagi disabilitas netra yang menjadi penunjang aktivitas penyandang disabilitas netra seharihari. Tidak jauh bebeda dengan kota- kota lain di Provinsi Banten, Kota Serang sebagai kota Provinsi sendiri masih banyak fasilitas umum khusus bagi penyandang disabilitas netra yang belum aksesibel dan belum sesuai fungsinya, atau dengan kata lain kurang ramah disabilitas. Padahal fasilitas tersebut disediakan oleh pemerintah setempat yang seharusnya dapat dipakai dan dapat bermanfaat bagi penyandang disabilitas netra agar dapat lebih mandiri dalam melakukan mobiliasasi. Aksesbilitas yang diterima oleh penyandang disabilitas pun akhirnya tidak bersifat mutlak, maksudnya fasilitas publik yang disediakan oleh pemerintah tidak dapat dikatakan aksesibel seperti yang sesuai pada pedoman dalam pembangunan fasilitas umum khusus disabilitas netra sebagai pengkhususan kebijakan (Hikmawan, 2017b). Padahal dalam prinsipnya setiap pembangunan gedung, fasilitas, dan lingkungan wajib harus memenuhi 4 azas, yaitu keselamatan, kemudahan, kegunaan, dan kemandirian. Sedangkan dalam merencanakan dan melaksanakan pembangunan gedung, fasilitas dan lingkungan harus dilengkapi dengan penyediaan fasilitas dan aksesbilitas wajib memenuhi persyaratan teknis fasilitas dan aksesibilitas.

\section{Gambar 1.1}

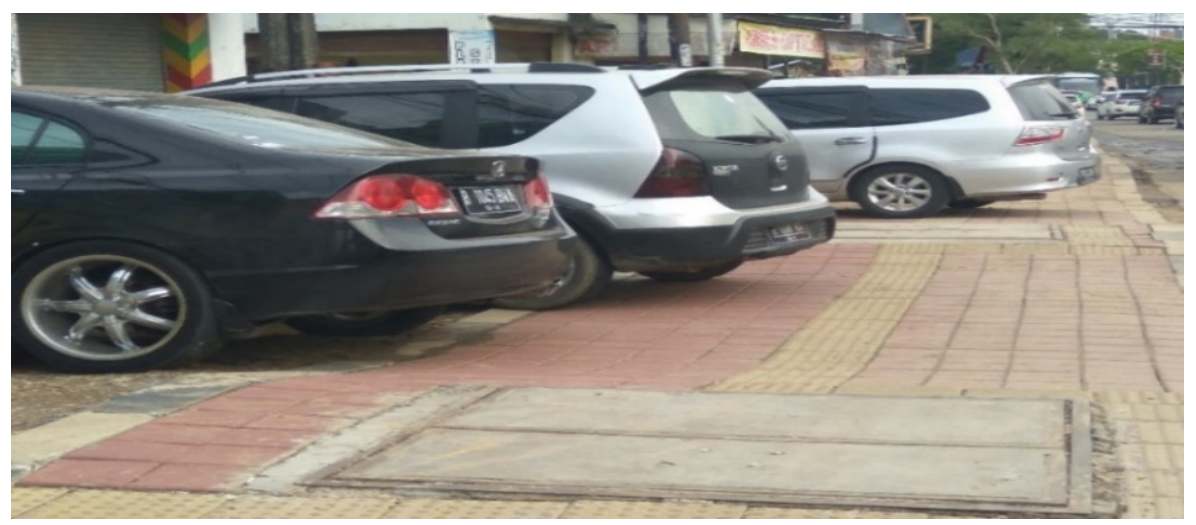

Gambar 1. Keadaan Trotoar Jl. Trip Jamaksari Kota Serang Tahun 2018, trotoar khusus (Guiding block) bagi disabilitas netra yang digunakan bagi tempat parkir.

Dari gambar diatas dapat dikatakan bahwa, fasilitas umum yang diterima oleh penyandang disabilitas hanyalah fasilitas "setengah hati" karena masih banyak fasilitas yang tidak sesuai fungsinya dan hanya sebagai hiasan yang tidak bisa digunakan oleh penyandang disabilitas. Di dalam UU No. 8 Tahun 2016 juga sudah tercantum di pasal 18 bahwa adanya hak aksesbilitas bagi penyandang disabilitas yang meliputi tentang hak dalam mendapatkan fasilitas publik dan akomodasi yang layak.

Begitupula dengan gedung- gedung pemerintah yang sering diakses oleh penyandang disabilitas. Salah satu contohnya seperti Dinas Sosial karena belum 
mempunyai gedung pemerintah sendiri, hanya bisa ruko maka yang terjadi fasilitas yang dibangun pun tidak di khususkan bagi penyandang disabilitas dan tidak sesuai dengan kriteria bangunan dengan fasilitas umum yang ideal bagi penyandang disabilitas.

\section{Gambar 2}

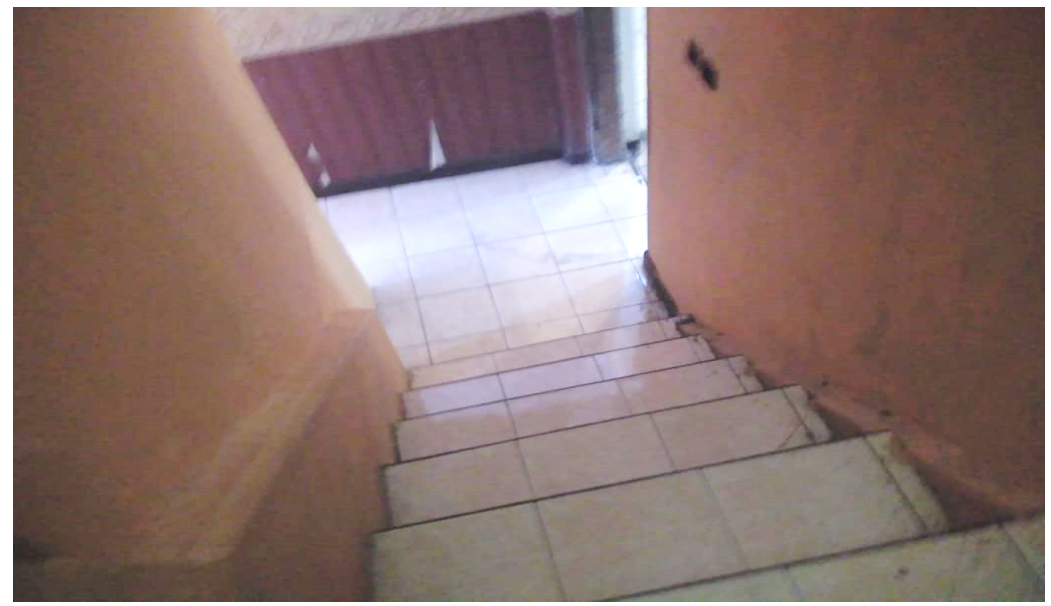

Gambar 3. Gedung Dinas Sosial Kota Serang, yang masih belum aksesibe/

Berdasarkan data di Dinas Sosial Kota Serang menurut hasil perhitungan perkecamatan yang dilaksanakan oleh Dinas Sosial, jumlah penyandang disabilitas di Kota Serang pertahun mulai dari tahun 2012 sampai tahun 2017.

Dari total jumlah 5 tahun terakhir terdapat sekitar 3.758 orang adalah penyandang disabilitas netra sebanyak 544 orang penyandang disabilitas rungu sebanyak 236 orang, penyandang disabilitas grahita/intelektual sebanyak 556 orang, penyandang disabilitas daksa/ tubuh sebanyak 1514 orang, penyandang disabilitas wicara sebanyak 482 orang dan sekitar 396 orang mengalami disabilitas ganda. Berikut adalah tabel Penyandang disabilitas di Kota Serang di tahun 2012 - 2017 :

Tabel 1.

Tabel Jumlah Penyandang Disabilitas Tahun 2012- 2017

\begin{tabular}{|c|c|c|c|c|c|c|c|}
\hline $\begin{array}{c}\text { Penyandang } \\
\text { Disabilitas }\end{array}$ & $\mathbf{2 0 1 2}$ & $\mathbf{2 0 1 3}$ & $\mathbf{2 0 1 4}$ & $\mathbf{2 0 1 5}$ & $\mathbf{2 0 1 6}$ & $\mathbf{2 0 1 7}$ & Jumlah \\
\hline $\begin{array}{c}\text { Disabilitas } \\
\text { Netra }\end{array}$ & 67 & 67 & 67 & 67 & 110 & 166 & 544 \\
\hline $\begin{array}{c}\text { Disabilitas } \\
\text { Wicara }\end{array}$ & 44 & 44 & 44 & 44 & 153 & 153 & 482 \\
\hline $\begin{array}{c}\text { Disabilitas } \\
\text { Rungu }\end{array}$ & 10 & 10 & 10 & 10 & 96 & 100 & 236 \\
\hline $\begin{array}{c}\text { Disabilitas } \\
\text { Daksa }\end{array}$ & 297 & 297 & 297 & 297 & 163 & 163 & 1.514 \\
\hline $\begin{array}{c}\text { Disabilitas } \\
\text { Mental }\end{array}$ & 51 & 51 & 51 & 51 & 152 & 200 & 556 \\
\hline $\begin{array}{c}\text { Disabilitas } \\
\text { Ganda }\end{array}$ & 49 & 49 & 49 & 49 & 100 & 100 & 396 \\
\hline \multicolumn{7}{|c|}{ Total Penyandang Disabilitas } \\
\hline
\end{tabular}

Sumber : Dinas Sosial Kota Serang 
Dengan penyandang disabilitas Netra yang semakin meningkat tiap tahunnya menurut data dari Dinas Sosial Kota Serang, seharusnya Kota Serang menjadi kota ramah lingkungan bagi penyandang disabilitas netra yang tujuan demi memudahkan mereka dalam beraktivitas sehari- hari. Dalam (Widiyanto, Hikmawan, \& Riswanda, 2019) implementasi ini harus dilakuakan dengan sangat baik agar berdampak langsung kepada penyandang disabilitas.

\section{Target Grup}

Penyandang disabilitas netra memerlukan kemudahan dalam mengakses setiap fasilitas umum yang memudahkan mereka dalam melakukan aktifitas sehari- hari. Mulai dari bangunan gedung publik yang didalamnya terdapat interior yang aksesibel begitupula dengan lingkungannya termasuk parkir yang aksesibel, jembatan penyebrangan yang aman bagi penyandang disabilitas, trotoar jalan yang sudah ada pemandu jalan berupa jalur kasar atau yang sering disebut dengan guiding block, dan toilet yang ramah disabilitas.

Berdasarkan hasil wawancara dengan ketua PERTUNI (Persatuan Tuna Netra) cabang Kota Serang, sebagian besar gedung- gedung publik yang biasa diakses oleh disabilitas netra belum memiliki pemandu dalam huruf braille disetiap kantor ataupun ruangannya. Dampaknya, penyandang disabilitas netra sendiri merasa kesulitan untuk menemukan ruangan yang ditujunya sebab tidak ada pemandu disetiap ruangan, selain itu perasaan tidak aman muncul dalam mengakses fasilitas publik seperti trotoar yang belum memiliki pemandu jalan dan jembatan penyebrangan yang sulit untuk diakses oleh disabilitas netra karena memang tangga untuk penyebrangan jalannya yang lama dan tidak terawat .

Bangunan gedung pemerintah yang sering diakses oleh penyandang disabilitas netra kota serang ialah kantor Dinas Kota Serang. Dalam hasil observasi yang peneliti temukan ialah pada bangunan gedung Dinas Sosial Kota Serang belum dapat dikatakan aksesibel karena mulai dari penempatan gedungnya yang berada dipinggir jalan tanpa adanya panduan jalan bagi disabilitas netra, serta bangunannya memiliki dua lantai sehingga memakai tangga untuk menghubungkan lantai pertama dan lantai kedua. Lantai pertama diperuntukan bagi sub bagian umum, sub bagian keuangan, dan sub bagian PEP. Sedangkan lantai dua untuk bidang pemberdayaan sosial, bidang pemberdayaan fakir miskin, bidang rehabilitasi sosial, dan bidang perlindungan dan jaminan sosial (Mahpudin, 2019). Padahal yang sering dikunjungi dan yang berhubungan langsung dengan penyandang disabilitas netra ialah bidang rehabilitasi sosial yang berada di lantai dua, sehingga memakai tangga untuk menghubungkan lantai pertama dan lantai kedua.

Keadaan tangga yang terlalu tinggi juga tidak hanya menyusahkan peyandang disabilitas khususnya disabilitas netra, namun juga non- disabilitaspun harus berhatihati jika melewati tangganya selain karena tinggi undakannya, tangganya juga tergolong sempit dan pencahayaan yang kurang menjadi rawan jatuh jika tidak hatihati.

Kebijakan tentang fasilitas publik yang harus aksesibel juga tercantum dalam Undang- undang Nomor 8 Tahun 2016 Tentang Penyandang Disabilitas pada Bagian Keempat Belas Hak Aksesbilitas pasal 18 disebutkan bahwa, hak penyandang Disabilitas meliputi hak: 
individu.

a. Mendapatkan aksesbilitas untuk memanfaatkan fasilitas publik dan;

b. Mendapatkan akomodasi yang layak sebagai bentuk aksesbilitas bagi

Selain wawancara dengan ketua PERTUNI dan hasil observasi di Dinas Sosial Kota Serang, peneliti juga mewawancarai sub. Bagian bangunan dan lingkungan Dinas Pekerjaan Umum dan Perumahan Rakyat Kota Serang terkait pembangunan gedung publik yang sudah ada bahwa aksesbilitas baik itu di dalam gedung seperti ruangan, toilet, dan juga lift begitu pula dengan lingkungan luar seperti parkir dan pelataran gedung yang belum dapat dikatakan aksesibel karena mengingat bangunan gedung publik tersebut sudah lama dan jika dipugar memerlukan anggaran yang tidak sedikit. Sedangkan bangunan baru yang sudah ada untuk jalan pemandu dipelataran gedungnya bagi disabilitas netra yaitu pada bangunan gedung DPRD Kota Serang.

Fasilitas umum yang lainnya ialah trotoar yang terdapat pemandu jalan atau guiding block. Hasil dari observasi dan wawancara peneliti, adanya tumpang tindih dalam pelaksanaan pembangunan trotoar di Kota Serang. Di tahun 2017 trotoar dijalan protokol Kota Serang, yaitu Jalan Ahmad Yani sampai Jalan Trip Jamaksari yang melaksanakan pembuatannya ialah Dinas Tata Kota Serang yang sekarang sudah berganti nama menjadi Dinas Permukiman Kota Serang padahal jalan tersebut merupakan jalan nasional yang seharusnya berwenang ialah kementrian pusat atau provinsi maka dari itu di Tahun 2018 diambil alih oleh Dinas Pekerjaan Umum dan Perumahan Rakyat (PUPR) Provinsi Banten karena jalan protokol tersebut merupakan ruas jalan nasional dan yang berwenang ialah provinsi, selain itu juga pembuatan trotoar ditahun 2017 tidak sesuai dengan pedoman teknis karena tidak mengakomodir pemenuhan hak aksesbilitas bagi penyandang disabilitas khususnya disabilitas netra. Tumpang tindih yang terjadi antara penyelenggara fasilitas publik yang ada di Kota Serang dan Provinsi Banten juga ialah karena kewenangan yang belum jelas dimana ruas- ruas jalan yang diamanatkan untuk kota dan provinsi.

\section{Badan Pelaksana}

Dalam memenuhi hak aksesbilitas bagi penyandang disabilitas khususnya disabilitas netra, pemerintah kota serang berkoordinasi dengan dinas- dinas terkait pembangunan fasilitas umum baik itu yang di memiliki ruangan seperti bangunan gedung publik ataupun fasilitas publik yang tempatnya diluar seperti jembatan penyebrangan ataupun trotoar khusus disabilitas.

Pembangunan gedung publik di Kota Serang dilaksanakan oleh Dinas Pekerjaan Umum dan Perumahan Rakyat (PUPR) Kota Serang, bidang cipta karya Sub. Bidang Bangunan Gedung dan Lingkungan yang memiliki tanggung jawab pada perencanaan pembangunan gedung, baik untuk gedung pemerintahan ataupun gedung milik swasta, yang mana dalam perencanaan sub.bidang ini merekomendasikan konstruksi bangunan yang didalamnya terdapat fasilitas- fasilitas yang akan dibangun sesuai dengan acuan peraturan teknis dalam pembangunan gedung. Dalam setiap pembuatan bangunan gedung publik ataupun fasilitas umum lainnya, biasanya para pelaksana tugas atau implementor tidak bekerja sendiri melainkan mencari pihak ketiga dengan cara melelang proyek pembuatan fisiknya.

Seperti yang dilakukan oleh Dinas Pekerjaan Umum dan Perumahan Rakyat (PUPR) Provinsi Banten yang melelang proyek pembuatan trotar di Jalan Ahmad 
Yani, Jalan Yusuf Martadilaga, dan Jalan Trip Jamaksari karena jumlah proyek tersebut bernilai diatas dua ratus juta rupiah maka Dinas Pekerjaan Umum dan Perumahan Rakyat (PUPR) Provinsi Banten membuka lelang online secara terbuka, selanjutnya pihak ketiga yang memenangkan lelang tersebut akan mengambil alih proyek dalam pembuatan trotoar. Selain itu Dinas Pekerjaan Umum dan Perumahan Rakyat (PUPR) Provinsi Banten bekerja sama dengan konsultan dalam membuat perencanaan dan mengawasi pembangunan trotoar.

Adapun faktor pendorong pemerintah untuk bekerjasama dengan pihak swasta ialah demi terciptanya efisien dan efektivitas pembangunan fasilitas umum.

\section{Faktor Lingkungan}

Stigma yang tertanam pada masyarakat bahwa penyandang disabilitas ialah suatu masalah sosial karena mempunyai keterbatasan pada kemampuan fisik atau motoriknya. Selanjutnya, stigma tersebut berdampak pada dikesampingkannya hakhak yang seharusnya diperoleh penyandang disabilitas . Masyarakat awam yang menganggap penyandang disabilitas netra tidak memiliki kemampuan apa- apa, atau pihak keluarga yang merasa malu dan takut jika lingkungan sekitarnya mengetahui bahwa mereka memiliki kerabat atau saudara yang berkebutuhan khusus.

Selain masyarakat, Pemerintah Kota Serang memiliki peran penting dalam memenuhi dan menyediakan fasilitas umum bagi penyandang disabilitas netra, karena bagaimanapun juga berhasil atau tidaknya suatu kebijakan jika para pelaksana bersikap baik dan konsisten terhadap suatu kebijakan tertentu (Hikmawan, 2017a), dalam hal ini dukungan, kemungkinan besar mereka melaksanakan kebijakan sebagaimana yang diinginkan oleh para pembuat keputusan awal. Demikian juga sebaliknya, bila tingkah laku atau perspektif para pelaksana berbeda dengan pembuat keputusan maka suatu proses pelaksanaan kebijakan menjadi sulit.

Dari hasil pembahasan yang sudah peneliti paparkan diatas, dapat dilihat bahwa implementasi hak aksesbilitas bagi penyandang disabilitas netra di kota serang belum dapat dikatakan ramah disabilitas. Hal ini terbukti pada penyediaan fasilitas umum yang disediakan oleh Pemerintah Kota Serang belum dapat dikatakan aksesibel dan sesuai dengan ketentuan pedoman teknis yang ditetapkan, hal ini berdampak pada kurang terpenuhinya hak- hak aksesbilitas yang diterima oleh penyandang disabilitas netra.

Belum adanya Peraturan Daerah Kota Serang yang menguatkan Undang- Undang Nomor 8 Tahun 2016 menjadi salah satu polemik bagi pemenuhan hak aksesbilitas yang diterima oleh penyandang disabilitas netra. Hak aksesbilitas ini juga termasuk kepada hak dasar manusia yang tidak boleh dibedakan antara non- disabilitas dan penyandang disabilitas karena berkaitan dengan harkat dan martabat manusia.

\section{Kesimpulan}

Implementasi hak aksesbilitas dalam UU No. 8 Tahun 2016 bagi penyandang disabilitas netra di Kota Serang masih belum optimal, hal ini bisa dilihat dari kurangnya kesiapan Pemerintah Kota Serang dalam menyediakan fasilitas- fasilitas publik yang bersifat fisik bagi penyandang penyandang disabilitas netra yang belum sesuai dengan fungsinya. Padahal undang- undang yang dibuat diawal dan sedang 
dijalankan saat ini, yaitu UU No. 8 Tahun 2016 sudah mejamin setiap hak- hak warga negaranya tanpa adanya diskriminasi.

Peyandang disabilitas netra ialah individu yang memiliki keterbatasan kemampuan dalam pengelihatannya, maka dari itu negara wajib melindungi masyarakatnya tanpa terkecuali. Maka dari itu lahirlah Undang- undang terbaru yaitu UU No. 8 Tahun 2016 Tentang Peyandang Disabilitas sebagai penyempurna dari UU sebelumnya yaitu UU No. 4 Tahun 1997 dan Undang- undang mengenai Konvensi Hak Penyandang Disabilitas yaitu UU No. 19 Tahun 2011.

Dalam Undang- undang terbaru, disebutkan dalam bagian keempat belas mengenai hak aksesbilitas, pasal 18 di menyebutkan bahwa ; (1) penyandang disabilitas mendapatkan aksesbilitas untuk memanfaatkan fasilitas publik. (2) penyandang disabilitas mendapatkan akomodasi yang layak sebagai bentuk aksesbilitas bagi individu. Namun dalam kenyataannya, Kota Serang dapat dikatakan belum menjadi Kota yang ramah disabilitas, hal ini terbukti dalam berbagai permsalahan yang sudah peneliti sebutkan di dalam pembahasan.

Pertama, Kebijakan mengenai penyandang disabilitaspun sudah tertuang dalam undang- undang terbaru, yaitu UU No. 8 Tahun 2016 Tentang Penyandang Disabilitas. Paradigma tentang penyandang disabilitaspun juga sudah bergeser, tidak lagi memandang penyandang disabilitas sebagai individu yang dikasihani dan masih dinilai sebagai masalah sosial seperti yang ada di UU No. 4 Tahun 1997, namun sebagai individu yang memiliki kesamaan hak dan bukan sebagai masalah sosial, penyandang disabilitas dilihat sama dan tidak boleh dibedakan berdasarkan ruang lingkup sosial dan ekonomi. Jadi penyandang disabilitas juga memiliki kesempatan yang sama dalam upaya pengembangan diri.

Sudah terhitung dua tahun sejak diberlakukannya UU No. 8 Tahun 2016 Tentang Penyandang Disabilitas. Namun sampai saat ini ditahun 2018, Kota Serang belum memiliki peraturan daerah ataupun peraturan walikota terkait tentang hak- hak penyandang disabilitas, hal ini disebabkan karena belum adanya tindak lanjut dari pemerintah provinsi banten yang sama- sama belum memiliki peraturan daerah ataupun peraturan gubernur tentang penyandang disabilitas. Padahal seharusnya pemerintah kota serang dapat mengakomodir setiap kebutuhan masyarakatnya tanpa terkecuali masyarakat dengan disabilitas netra.

Dalam melakukan perumusan dan perencanaan untuk membuat kebijakan yang ideal juga seharusnya dibutuhkan tenaga terampil dan keterlibatan langsung dari kelompok yang bersangkutan, misalnya dalam hal ini Perda yang akan dibuat oleh Pemerintah Kota Serang bisa melibatkan lembaga atau organisasi yang berhubungan dengan penyandang disabilitas, lebih bagusnya lagi dengan individu- individu yang merasakan langsung apa yang menjadi kebutuhan dari penyandang disabilitas khususnya disabilitas netra. maka dari itu hal ini mempermudah para implementor dalam menjalankan kebijakan yang akan dibuat.

Kedua, hak aksesbilitas yang didapatkan oleh penyandang disabilitas netra di Kota Serang belum optimal. Penyandang disabilitas netra memerlukan kemudahan dalam setiap mengakses fasilitas umum, namun kenyataannya masih banyak fasilitas umum di Kota Serang yang belum aksesibel berdasarkan wawancara dengan informan PPDI dan PERTUNI sebagian besar gedung- gedung publik milik pemerintah belum dapat diakses dengan mudah oleh disabilitas netra, contohnya gedung- gedung 
pemerintah yang sering dikunjungi seperti Dinas Sosial Kota Serang tidak memiliki pemandu berupa huruf braille disetiap ruangannya, dampaknya penyandang disabilitas netra sendiri merasa kesulitan untuk menemukan ruangan yang dituju. Selain itu fasilitas lain yang ada di Kota Serang bagi disabilitas netra ialah trotoar jalan yang belum sesuai dengan kebutuhan disabilitas netra karena keadaan trotoar yang tidak sesuai ini memunculkan rasa tidak aman bagi penyandang disabilitas netra ini.

Ketiga, badan pelaksana yang berwenang dalam memenuhi hak aksesbilitas netra ialah Dinas Sosial Kota Serang Bidang Rehabilitasi Sosial, karena bidang tersebut mempunyai tugas terkait pelayanan dan kebutuhan penyandang disabilitas. selain itu Dinas Pekerjaan Umum Kota Serang Bagian Cipta Karya Sub. Bagian Bangunan Gedung Dan Lingkungan yang memiliki tanggung jawab dalam setiap perencanaan dalam pembangunan gedung publik ataupun gedung swasta. serta dinas pekerjaan umum dan perumahan yang berwenang dalam pembuatan trotoar di jalan nasional seperti Jalan ahmad yani, Jalan Yusuf Martadilaga, dan Jalan Trip Jamaksari ditahun 2018 yang pembangunannya berpedoman pada Peraturan Menteri Pekerjaan Umum No. 30 Tahun 2006 Tentang Pedoman Teknis Fasilitas Dan Aksesbilitas Pada Bangunan Gedung Dan Lingkungan. Keempat, masih banyaknya pandangan masyarakat Kota Serang terhadap penyandang disabilitas masih awam dan juga menganggap penyandang disabilitas netra yang tidak memiliki kemampuan apa- apa. selain itu di dalam lingkungan keluarga pun masih banyak yang malu mengakui jika mempunyai saudara ataupun kerabat yang berkebutuhan khusus karena takut jika lingkungan sekitar mengetahuinya. stigma- stigma tersebut yang tertanam pada masyarakat bahwa penyandang disabilitas merupakan masalah sosial yang harus dikasihani.

\section{Referensi}

Agus. "Gambaran Umum Daerah Kota Serang". Diakses melalui http://dprdserangkota.go.id/gambaran-umum-daerah-kota-serang/ pada Hari Rabu tanggal 23 Mei 2018, 5:00

Aisyah, Siti. 2015. Implementasi Kebijakan Aksesibilitas Pelayanan Bagi Difabel Di Yogyakarta Tahun 2015 (Studi Kasus: Grhatama Pustaka Yogyakarta). Yogyakarta: FISIP, Universitas Muhadiyah YogyakartaAgus. "Gambaran Umum Daerah Kota Serang". Diakses melalui http://dprd-serangkota.go.id/gambaran-umumdaerah-kota-serang/ pada Hari Rabu tanggal 23 Mei 2018, 5:00

Akin, Haedar. 2010. Jurnal Administrasi Negara: Impelementasi Kebijakan (Apa, Mengapa, dan Bagaimana). Volume 1 No. 1 Thn. 2010. Hal 3

Andi, Prastowo. 2011. Memahami Metode Penelitian: Suatu Tinjauan Teoritis dan Praktis. Yogyakarta: Ar-Ruzz Media 
Apriyani, Novita. 2012. Aksesbilitas Penyandang Disabilitas Pengguna Alat Bantu Gerak Pada Bangunan Institusi Pendidikan (Studi Kasus: Universitas Indonesia). Depok: Universitas Indonesia.

Arinia, I., Hikmawan, I. M. D., \& Ma'asan Mayrudin, Y. (2019). The Movement of Women with Disabilities on Indonesia's Legislative Election 2019.

Aziz, Letty. 2016. Politik Pengelolaan Dana Ekonomi Khusus dan Istimewa. Jakarta: Yayasan Pustaka Obor Indonesia

Couldry, Nick, Sonia Livingstone, dan Tim Markham. 2007. Media Consumption and Public Engagement: Beyond the Presumption of Attention. New York: Palgrave Macmillan.

Creswell W. Jhon. 2010. Research Design; Pendekatan Kualitatif, Kuantitatif dan Mixed. Yogyakarta: Pustaka Pelajar

Dewi, Putu Mia Rismari. 2016. Aksesbilitas Penyandang Disabilitas Di Halte Dan Bus Trans Jogja Di Kota Yogyakarta. Yogyakarta : Universitas Atma Jaya

Eko Riyadi, at.al, 2012, Vulnerable Groups: Kajian dan Mekanisme Perlindungannya, Yogyakarta: PUSHAM UII

Ghani, Syahrul Almas. 2017. Analisis Impelentasi Pelayanan Publik Transportasi Umum (Transjakarta Cares). Malang : Universitas Brawijaya.

Gatra, sandoro . “Konvensi Hak Penyandang Disabilitas Diratifikasi”. Diakses melalui https://nasional.kompas.com/read/2011/10/18/14234311/ pada Hari Minggu tanggal 11 Maret 2018, 21:12

Hasanah, B. 2017. Pelayanan Aksesbilitas jalan Umum (Jalur Pendestrian) Bagi Penyandang Disabilitas (Studi Kasus: Di Kota Serang). Journal of Social Science Volume 1 Nomor 1. Hal 60- 78

Hikmawan, M. D. (2017a). Pluralisme Demokrasi Politik di Indonesia. Journal of Governance, 2(2), 223-247. https://doi.org/http://dx.doi.org/10.31506/jog.v2i2.2678

Hikmawan, M. D. (2017b). Politik Perbedaan: Minnoritas dalam Implementasi Kebijakan. Journal of Indonesian Public Administration and Governance Studies (JIPAGS), 1(1), 88-98.

Hosni, Irham. 2008. Tuna Netra dan Kebutuhan Dasarnya. Bandung: Universitas Pendidikan Indonesia. 
Lestari, Eta Yuni. Aksesbilitas Bagi Penyandang Disabilitas Kabupaten Semarang melalui Impelementasi CPRD dalam Bidang Pendidikan. Integralistik Volume 1 Nomor 1, Januari- Juni 2017.

Mahpudin. (2019). Demokrasi dan Kebangkitan Politik Identitas: Refleksi Perjalanan Demokrasi Indonesia Pasca Orde Baru. International Journal of Demos, 1(1), 1-18.

Media Centre Hukum dan Ham. "Indonesia, Negara ke-107 Meratifikasi Konvensi Hak Penyandang Disabilitas" diakses melalui https://kumparan.com/media-centerkementerian-hukum-dan-ham/indonesia-negara-ke-107-meratifikasi-konvensihak-penyandang-disabilitas-1512729085626 pada Hari Minggu tanggal 11 Maret 2018, 21:24

Moleong, Lexy J. 2010. Metode Penelitian Kualitatif. Bandung: Remaja Rosdakarya

Neuman, W. L. 2003. Social Research Methods: Qualitative and Quantitative Approach. Boston; Allyn and Bacon

Nuraviva, Lelly. 2017. Aksesbilitas Penyandang Disabilitas Terhadap Fasilitas Publik Di Kota Surakarta. Semarang : Universitas Diponegro

Nurannisa, Fadiah. 2016. Aksesbilitas Dan Fasilitas Publik Kaum Difabel Di Margonda Raya, Kota Depok. Jakatra: Universitas Guna Dharma

Nugroho, Riant. 2014. Public Policy: Teori, Manajemen, Dinamika, Analisa, Kovergensi, Dan Kimia Kebijakan. Jakarta: PT. Elex Media Komputindo

Peláez, Patricia López. 2007. Urbanisme Dan Perumahan Yang Mudah Diakses Untuk Penyandang Disabilitast: Kasus Spanyol. Contexto: Revista de la Facultad de Arquitectura Universidad Autónoma de Nuevo León. Universidad Autónoma de Nuevo León

Peraturan Mentri No. 30 Tahun 2006 Tentang Pedoman Teknis Fasilitas Dan Aksesibilitas Pada Bangunan Gedung Dan Lingkungan

Perwitasari, Puspa. “Hanya Delapan Provinsi Memiliki Perda Disabilitas”. Diakses melalui http://news.metrotvnews.com/peristiwa/GKdQJjmN-hanya-delapanprovinsi-memiliki-perda-disabilitas pada Hari Rabu tanggal 22 Agustus 2018, 21:02)

Raharja, Djaja. 2018. Skripsi : Ketunanetraan.. Universitas Pendidikan Indonesia

Ratnaningsih, Erna. “Pergeseran Paradigma Tentang Penyandang Disabilitas Dalam $\begin{array}{lllll}\text { UU } & \text { No. } & 8 & \text { Tahun } & 2016 .\end{array}$ 
http:// businesslaw.binus.ac.id/2016/04/29/pergeseran-paradigma-tentangpenyandang-disabilitas-dalam-uu-no-8-tahun-2016/ pada Hari Minggu tanggal 19 Agustus 2018, 21:45

Rina Herlina, C.S. 2017. Aksesibilitas Pariwisata Bagi Difabel di Kota Surakarta (Studi Evaluasi Peraturan Mentri Pekerjaan Umum No. 30 Tahun 2006 Tentang Pedoman Teknis Fasilitas dan Aksesibilitas Pada Bangunan Gedung dan Lingkungan). Spirit Publik Volume 12. Nomor 1, April 2017, 85- 96

Rizkyani, Fatimah. 2016. Skripsi: Hubungan Manusia dengan Kebutuhan Dasar. Yogyakarta: Universitas Negri Yogyakarta

Rosyada, Dede, 2007, Paradigma Pendidikan Gratis: Sebuah Model Pelibatan Masyarakat Dalam Penyelenggaraan Pendidikan, Jakarta: Kencana Prenaga.

Ryaas Rasyid, 1998. Desentralisasi Dalam Menunjang Pembangunan Daerah Dalam Pembangunan Administrasi di Indonesia, Jakarta: PT. Pustaka LP3ES

Sapto Nugroho, Risnawati Utami, 2008, Meretas Siklus Kecacatan-Realitas Yang Terabaikan, Surakarta: Yayasan Talenta,

Sugiyono. (2009). Metode Penelitian Bisnis (Pendekatan Kuantitatif, Kualitatif, dan RED). Bandung: Alfabeta.

Undang- Undang Dasar Negara Republik Indonesia Tahun 1945

UU No. 4 Tahun 1997 Tentang Penyandang Cacat

UU No. 11 Tahun 2009 Tentang Kesejahteraan Sosial

UU No. 22 Tahun 2009 Tentang Lalu Lintas dan Angkutan Jalan

UU No. 19 Tahun 2011 Tentang Pengesahan Convention On The Rights Of Persons With Disabilities

UU No. 8 Tahun 2016 Tentang Penyandang Disabilitas

Visagie, Surona. "Policy Implementation in Wheelchair Service Delivery in A rural South African Setting". melalui https://ajod.org/index.php/ajod/article/view/63 pada Hari Selasa tanggal 18 Maret 2018, 10:19

Widiyanto, A., Hikmawan, M. D., \& Riswanda, riswanda. (2019). JSPG: Journal of Social Politics and Governance Implementasi Rencana Aksi Nasional Bela Negara Berdasarkan Instruksi Presiden Nomor 7 Tahun 2018 Oleh Dewan Ketahanan 
Nasional Republik Indonesia. Journal of Social Politics and Governance, 1(2), 95-115.

Winarno, Budi. 2013. Kebijakan Publik: Teori, Proses, dan Studi Kasus. Yogyakarta: CPAS (Centre of Academic Publishing Service)

Wirawan, I.B. 2007. Aksesibilitas Penyandang Cacat di Jawa Timur. Surabaya: Universitas Airlangga 